تأثير يك دوره فعاليت بدنى هوازى و مكمل يارى اكتايامين بربيان اينفلامازوم PI3k NLRP1، آيويتوزيس

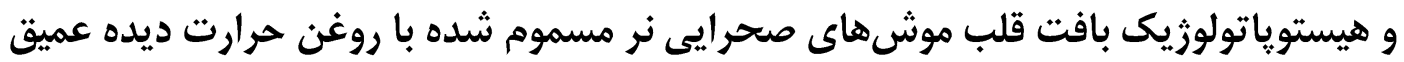

\author{
محبوبه كاظمى درهبيدى'، مقصود بيرى ×x، محمدعلى آذربايجانى
}

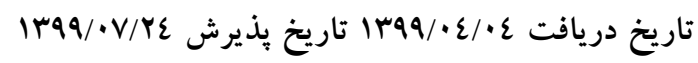

\begin{abstract}
جָكـده
ويشزمينه و هدف: اشتباهات رايج تغذيهاى باعث التهاب و تخريب هومئوستاز سلولهاى قلبى مىشود. ازجمله مسيرهايى كه سبب القاى التهاب و تخريب بازسازى يروتئينهاى قلبى مىشود كميلكس اينفلامازوم مىباشد. هدف از مطالعه حاضر بررسى تغييرات اينفلامازوم NLRP1، PI3k، آيويتوزيس و

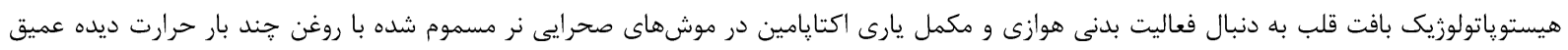
(DFO)

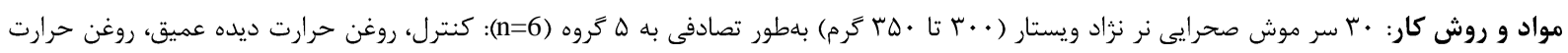

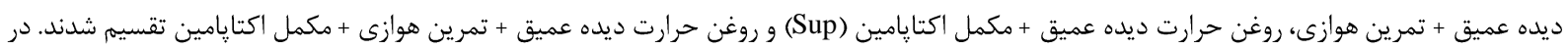

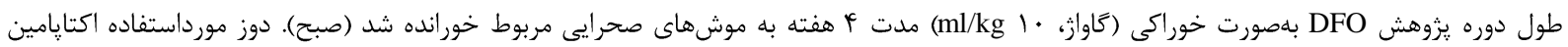

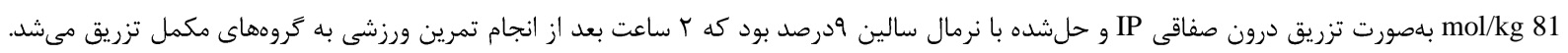

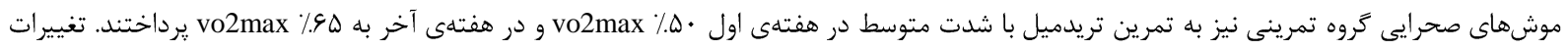

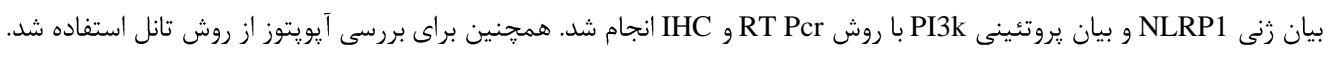
يافتهها: مصرف DFO افزايش معنى دارى در تخريبات بافتى (P=0.001) و رسوب كلاثن (P=0.001) به بافت قلب ايجاد كرد. همجنين كاواز

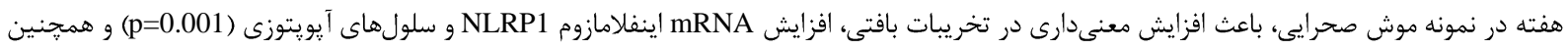

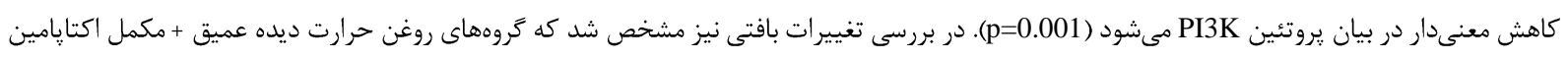

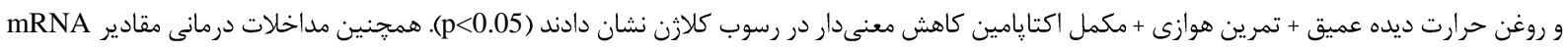

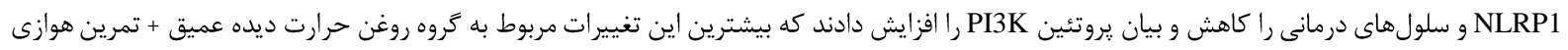

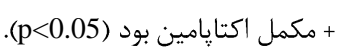
بحث و نتيجه كيرى: نتايج مطالعه حاضر نشان داد كه مصرف اكتإيامين همراه با تمرين ورزشى هوازى به مدت ع ع هفته قادر به كنترل كميلكس اينفلامازوم

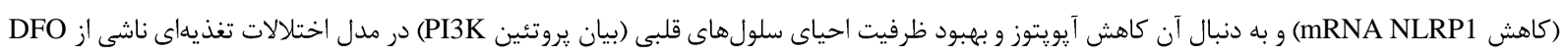
است. لذا مى توان بيان كرد كه مكمل يارى اكتايامين با تمرين ورزشى مىتواند تأثيرات حفاظت قلب در شرايط تغذيه غيرهوشمندانه داشته باشد. كليدوازهها: كميلكس اينفلامازوم، فعاليت بدنى هوازى، روغن حرارت ديده عميق، قلب، آيويتوزيس

مجله مطالعات علوم بزشكى، دوره سى و يكم، شماره نهم، ص 77V-7V9 ، آذر Irq9

آدرس مكاتبه: تهران، دانشكاه آزاد اسلامى، واحد تهران مركزى، كروه فيزيولوزى ورزشى، تلفن: Email: m.peeri@iauctb.ac.ir

بيمارى قلبى عروقى (CVD) عامل اصلى مرگ عومير در سراسر

مقدمه

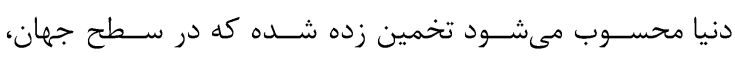

اخروه فيزيولوزى ورزشى، دانشعاه آزاد اسلامى، واحد تهران مركزى، تهران، ايران

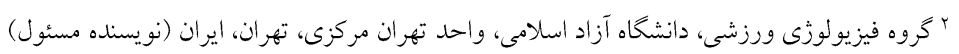

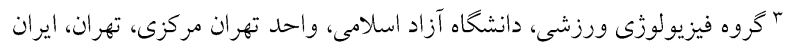


محصـــولات باعث توليد راديكال هاى آزاد، مولكول هاى قطبى و

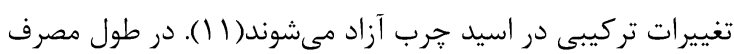

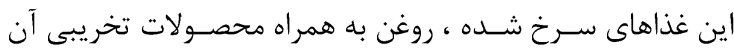

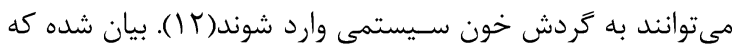

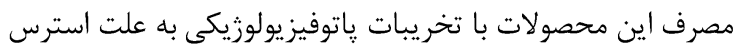

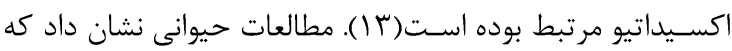

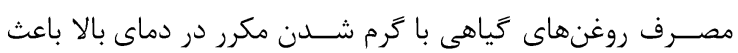

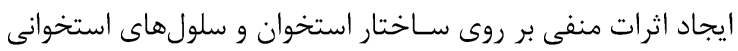
در موشهاى صـحرايى اوركتومى و افزايش بروز فشارخون، اختلال

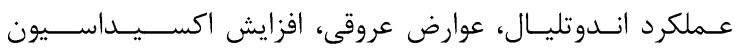

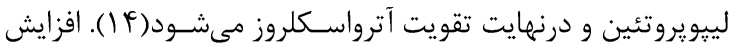

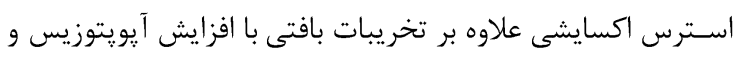

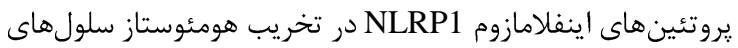
عضله قلبى نقش دارد. كَســترش التهـاب ازجمله عوامل القاكننده بيمارىهاى قلبى عروقى بهويزه آترواسـكولروزيس مي مباشد. NoD-like receptors

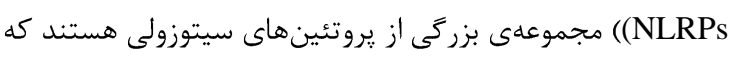

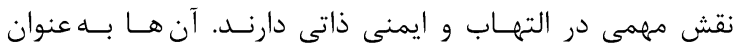

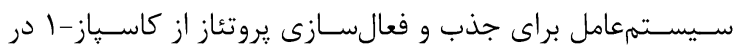

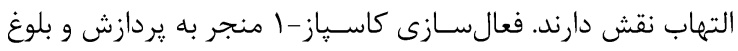

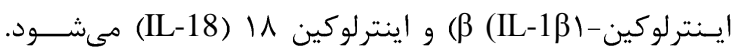
مكانيسمهاى التهابى NLRP1 در شرايط اشتباهات تغذيهاى نظير DFO كه منجر به التهاب مىشـود مشخص نشده است (هابى (1). بيان

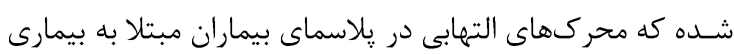

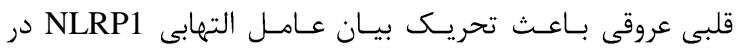

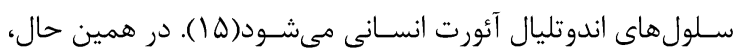
بهبود سبك زندگى با تمرين ورزشى و مصرف مكمل هاى گياهى و

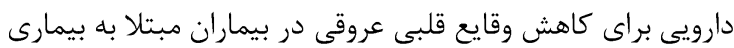
عروق محيطى نشان داده شده است(19). انجام تمرين ورزشى منظم يك استراترى غير دارويى است كه

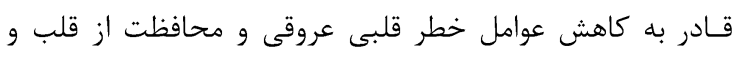

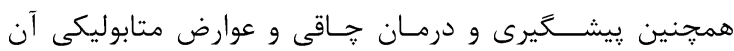

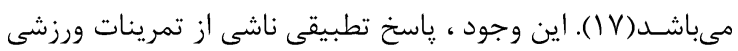

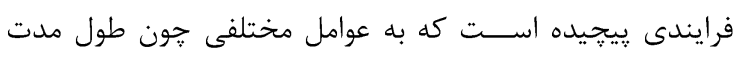

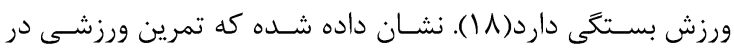
بافت قلبى قادر به بهبود رمودلينگ قلبى با تقويت مسـير سيخنالى داردي AKT/PI3K ورزشى در بافت قلب مشاهده شده است. بيان شده كه مهار PI3K بـا داروهاى مختلف بقاى ســلولهاى آيويتوزى را تحت تأثير قرار
זسادرصـــد از كل مركَوميرها مربوط به بيمارىهاى قلبى عروقى

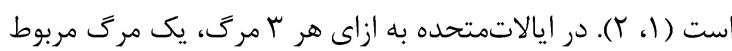

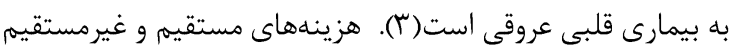

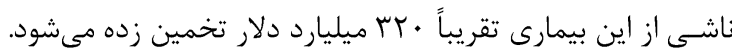

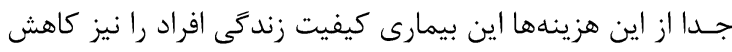

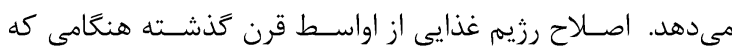

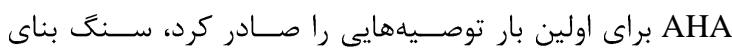
ييشـخيرى از CVD بوده اسـت. براى اكثر قريب به اتفاق توجهات

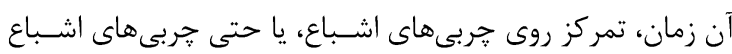

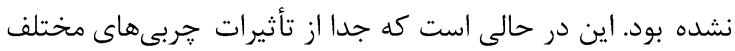
در القاى بيمارىهاى قلبى عروقى، نوع يختو يز و دمايى كه جربى

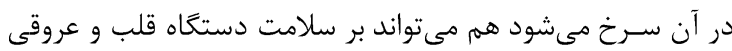
نيز تأثير بخذارد.

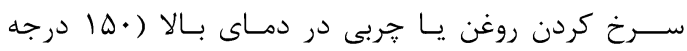

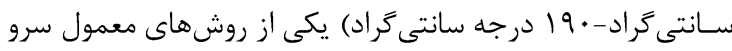
غذا است كه به دليل وجود رنى بهتر غذا، طعم و بافت غذاى سرخ

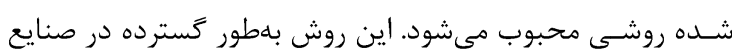

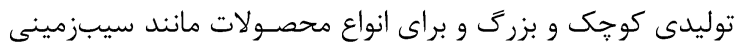

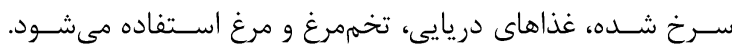

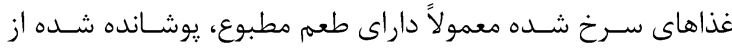

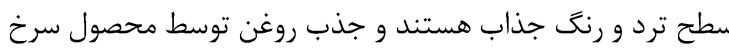

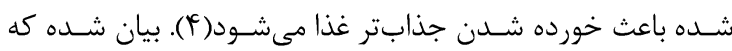

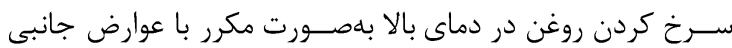

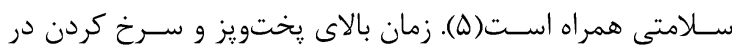

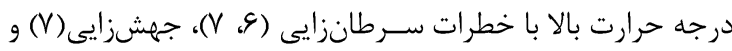

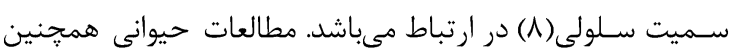

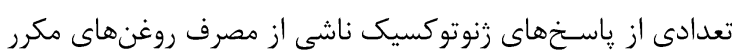

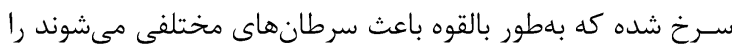

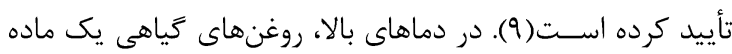

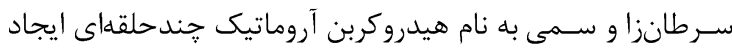

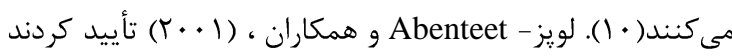

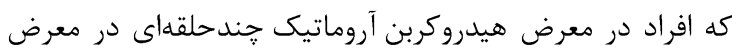

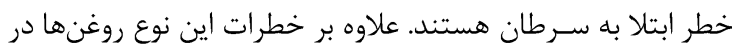

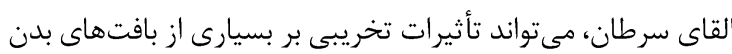
بلهويزه دستغاه قلبى عروقى داشته باشد.

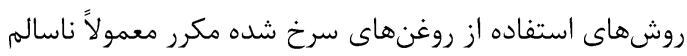

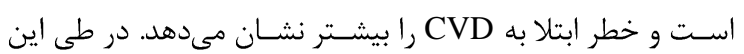

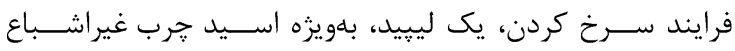

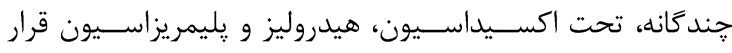

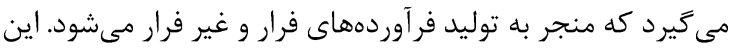


اسـاس ضـوابط كميته اخلاقى حيوانات دانشخاه آزاد اسلامى تهران

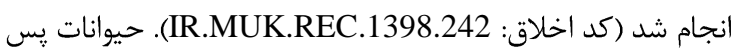
از يك هفته آشــاسـازى با محيط آزمايشـعاه بهصورت تصادفى به

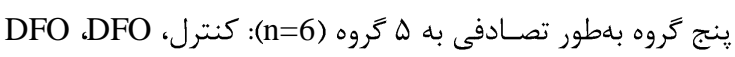

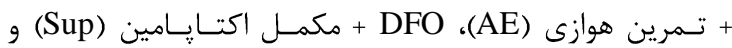
DFO+AE+Sup

القاى مسموميت با DFO:

بممنظور تهيهى روغن حرارت ديده بر اساس مطالعات ييشين

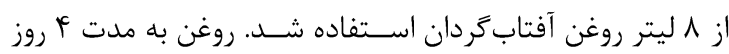

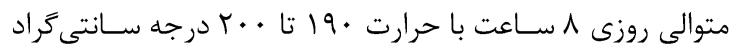
داغ شـــده و طبق منابع هر ·ـ دقيقه مواد غذايى: ناگت مرغ،

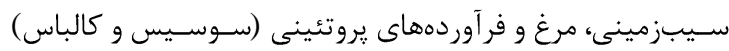

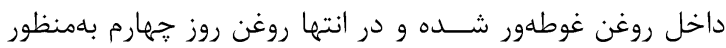

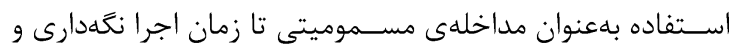

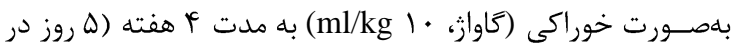
هفته) به موشهاى صحر ايى خورانده شد(T) (T). كاواز روغنسوخته

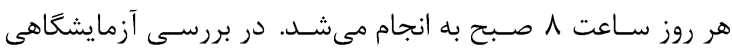
روغن مشخص شد كه DFO تهيهشده حاوى هيدروير اكسيد جربى رونى

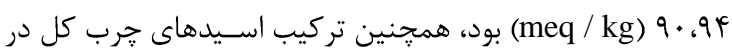
جدول ا نشان داده شده است.

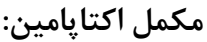

مكمل مورداستفاده در اين تحقيق اكتايامين بود كه به مدت

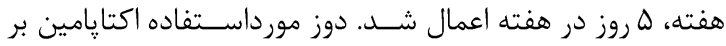

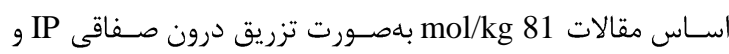
حلشـده با نرمال سـالين 9 \% مىباشـد(TF) كه دو ساعت بعد از انجام تمرين ورزشسى تزريق انجام مىشد. مكمل از شركت سيخما آلدريج تهيه شد (Sigma-Aldrich, St. Louis, MO).

\section{بروتكل تمرينى:}

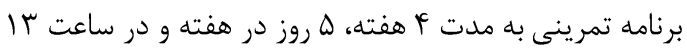

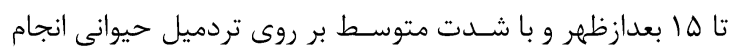
يذيرفت (Tajhiz gostar Iranian, Model 2016). بر اســاس ونس مطـالعات شــدت تمرين در هفتهى اول 50\% vo2max و در

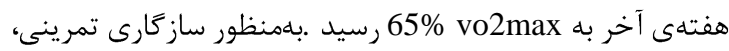

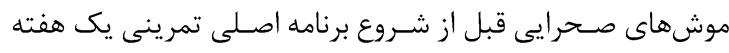

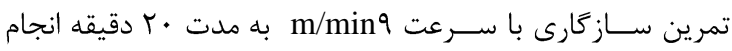

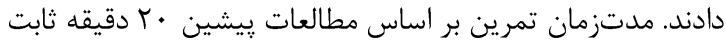

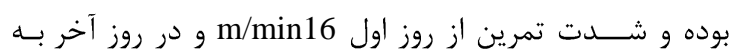
m/minV رسيد. براى شروع تمرين ه دقيقه با سرعت إست

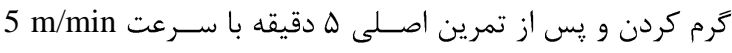

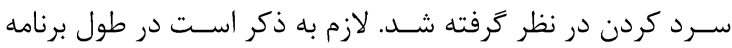

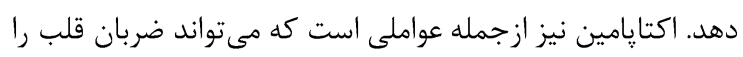
تحت تأثير قرار دهد.

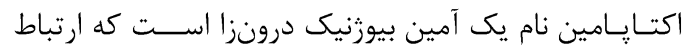

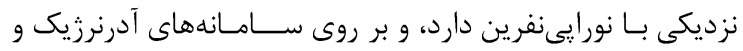

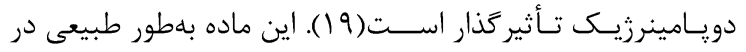
كَاهان متعدد مانند نارنج موجود است. بيوسنتز اكتايامين بهوسيله

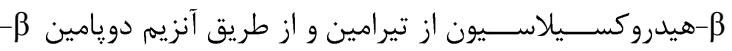

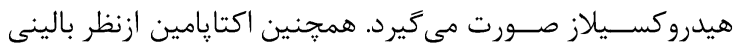

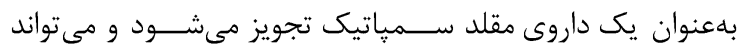
عملكرد قلب و سـلول هاى قلبى را تحت تأثير قرار دهد. در رابطه با ديا تأثير اكتايامين در تمرين ورزشى بيان شده كه تمرين ورزشى حلى حاد

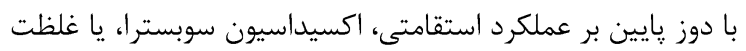

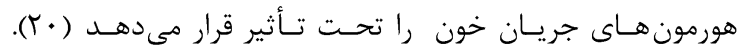

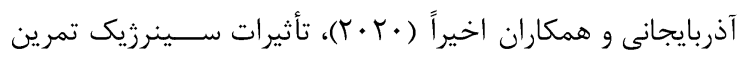

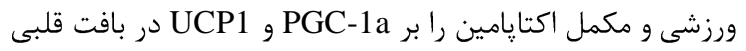
موشهاى صحر ايى با مصـرف DFO موردبر رسى قرار داده و بيان

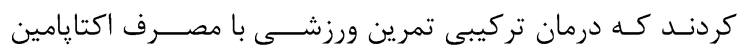

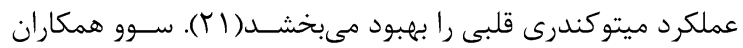
(Y. IV)

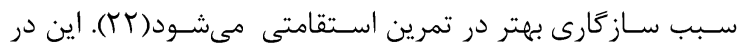

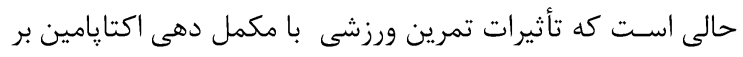
كنترل ريسك فاكتورهاى بيمارى قلبى عروقى بهويزه مسير التهابى لماتى

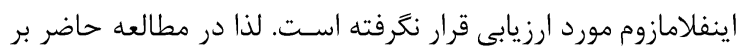

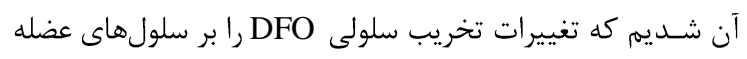

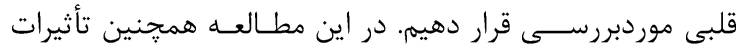

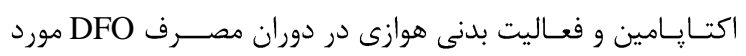
ارزيابى قرار مى كيرد.

\section{مواد و روش كار حيوانات و كروهبندى:}

در يزوهش حاضـر · r سـر موش صـحر ايى نر نزاد ويستار 19

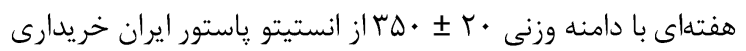
شــند. يس از انتقال موشهاى صـحرايى به محيط جديد حيوانات

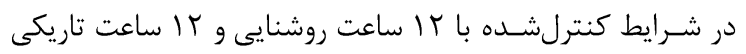

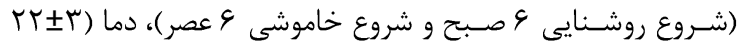

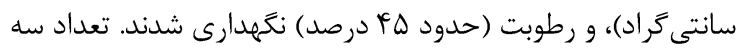

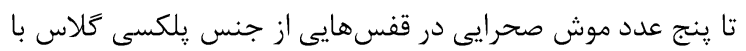

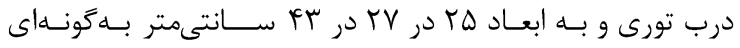

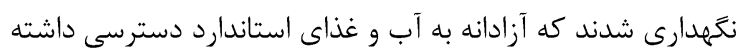

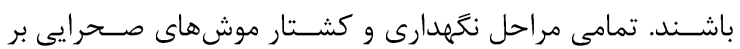




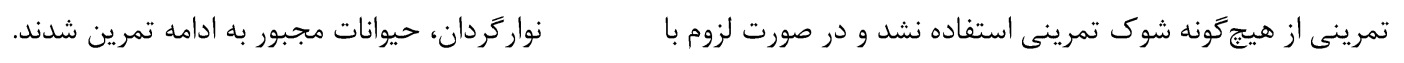

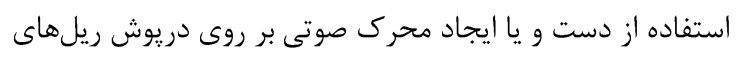

جدول(1): كروماتوكرام و تركيب اسيدهاى جرب كل براى DFO

FID1
\begin{tabular}{|c|c|c|c|c|c|}
\hline Peak\# & Ret. Time & Area & Height & Area $\%$ & Name \\
\hline 1 & 8.656 & 2815 & 1503 & 0.183 & C $12: 0$ \\
\hline 2 & 9.268 & 9363 & 5572 & 0.607 & C $14: 0$ \\
\hline 3 & 10.108 & 334877 & 166330 & 21.715 & C $16: 0$ \\
\hline 4 & 10.397 & 3634 & 1687 & 0.236 & \\
\hline 5 & 10.451 & 35710 & 17566 & 2.316 & C $16: 1$ \\
\hline 6 & 10.660 & 2205 & 1022 & 0.143 & C $17: 0$ \\
\hline 7 & 11.058 & 1336 & 536 & 0.087 & C $17: 1$ \\
\hline 8 & 11.390 & 87737 & 35935 & 5.689 & $\mathrm{C} 18: 0$ \\
\hline 9 & 11.766 & 13205 & 3807 & 0.856 & $\mathrm{C} 18: 1 \mathrm{t}$ \\
\hline 10 & 11.864 & 607740 & 205169 & 39.410 & $\mathrm{C} 18: 1 \mathrm{c}$ \\
\hline 11 & 12.491 & 5220 & 1700 & 0.338 & $\mathrm{C} 18: 2 \mathrm{t}$ \\
\hline 12 & 12.586 & 8008 & 2810 & 0.519 & $\mathrm{C} 18: 2 \mathrm{t}$ \\
\hline 13 & 12.687 & 375676 & 132580 & 24.361 & $\mathrm{C} 18: 2 \mathrm{c}$ \\
\hline 14 & 13.433 & 8743 & 1644 & 0.567 & $\mathrm{C} 20: 0$ \\
\hline 15 & 13.742 & 4289 & 1088 & 0.278 & $\mathrm{C} 18: 3 \mathrm{t}$ \\
\hline 16 & 13.857 & 25153 & 8150 & 1.631 & $\mathrm{C} 18: 3 \mathrm{n} 3$ \\
\hline 17 & 14.134 & 6940 & 2151 & 0.450 & $\mathrm{C} 20: 1$ \\
\hline 18 & 14.349 & 1698 & 317 & 0.110 & \\
\hline 19 & 15.421 & 1212 & 355 & 0.079 & \\
\hline 20 & 16.656 & 4868 & 1185 & 0.316 & $\mathrm{C} 22: 0$ \\
\hline 21 & 19.970 & 1683 & 540 & 0.109 & $\mathrm{C} 24: 0$ \\
\hline Total & & 1542115 & 591647 & 100.000 & \\
\hline
\end{tabular}

بامنظور بازيابى آنتىثنى، در بافر pH:9.2) TBS1X) به مدت

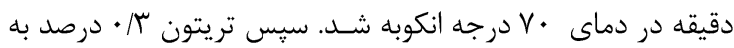

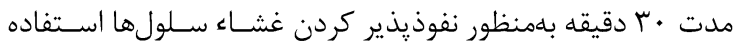

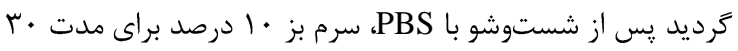

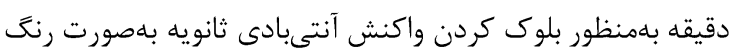

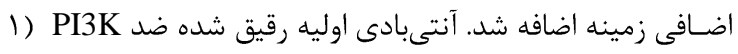

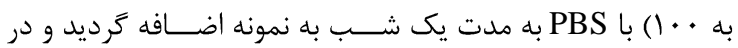

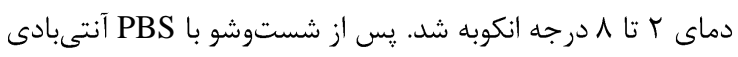

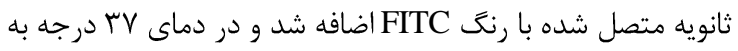

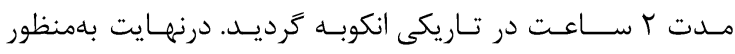
رنعآميزى هسـته، به نمونهها DAPI اضــافه شــــ در مرحله آخر

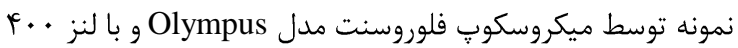
براى تأييد ماركرها مشاهده شدند.

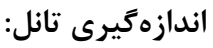

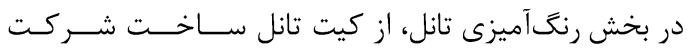

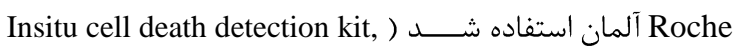

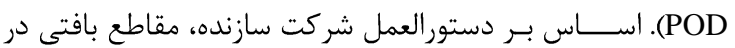

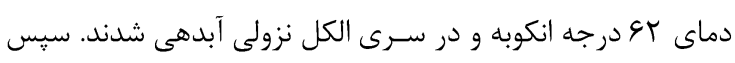

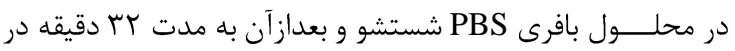

ارزيابىهاى بافتى (H\&E و ترى كروماسون):

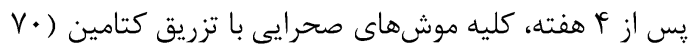

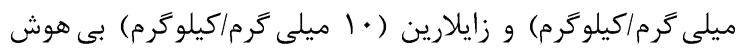

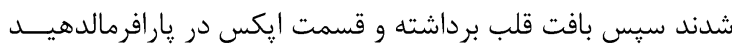
F أدرصد به مدت يك شبانهروز در دمـاى F أ درجـه سانتى

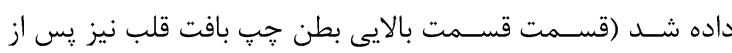

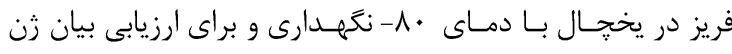

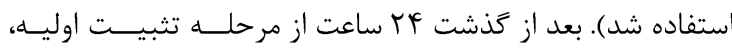

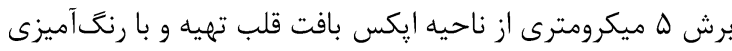
H\&E

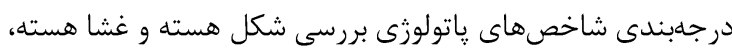

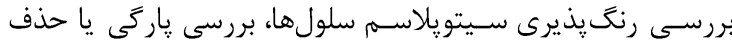

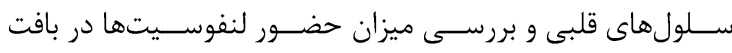

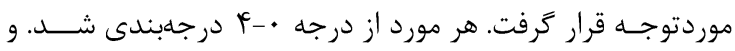

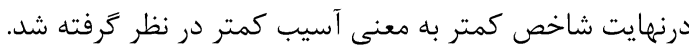
بررسى ايمونوهيستوشيمى:

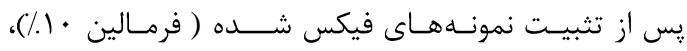

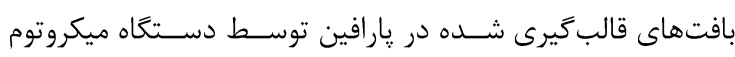

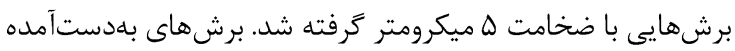


انجماد خرد شد و بهمنظور ليز نمونهها ميزان . ال لاندا كلروفرم به

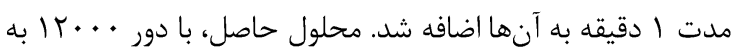
مدت • ا دقيقه سـانتريفيوز گرديد. مايع شفاف قسمت بالايى لوله

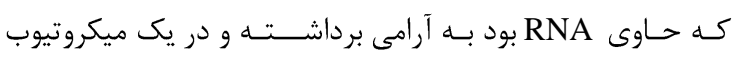

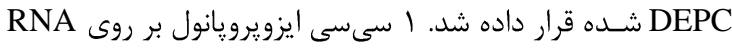
شفاف ريخته شد و به مدت ا دقيقه با دستبههم زده شد. نمونهها

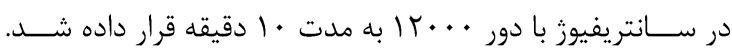
سيس مايع رويى دور ريخته شد و روى رسوب آن ا سىسى سي الكل

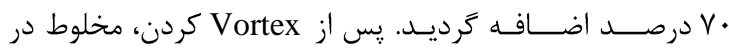

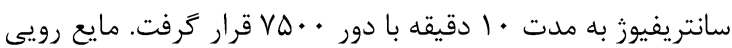

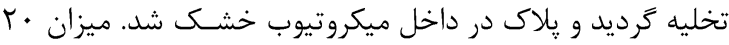

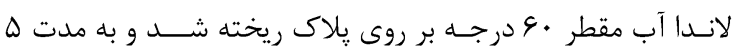
دقيقه بر روى صـفحهى •و درجه قرار داده شــ. يس از اسـتخراج

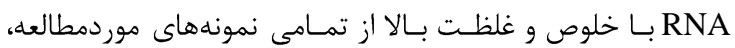

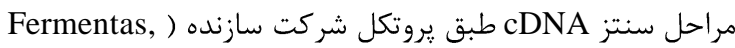

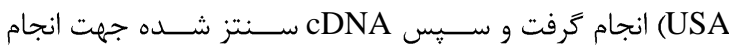

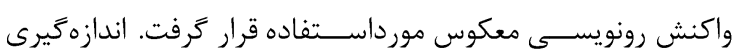
ســوح بيان RLRP1 از روش كمى Real time-Pcr انجام شــد. طراحى يرايمرها بر اساس اطلاعات زنهاى NLRP1 و لمان

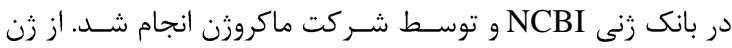
كليســـرآلدهيد-بـفسـفـات دهيدروزناز (GAPDH)بهعنوان زن كنترل استفاده كرديد و ميزان بيان زن موردنظر با فرمول

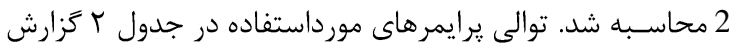
شده است.
دماى 37 درجه سـانتى گراد با محلول يروتئيناز K مجاور كرديدند.

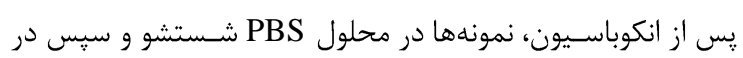
مجاورت محلول واكنش تانل به مدت ك بودقيقه در دماى لr د درجه

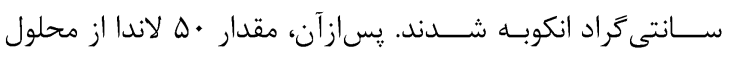
كConverter-POD

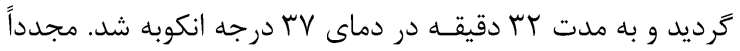

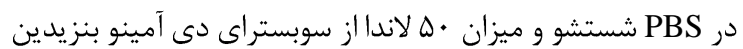

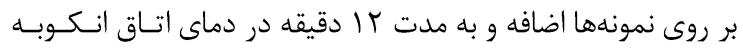

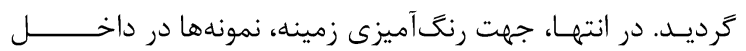

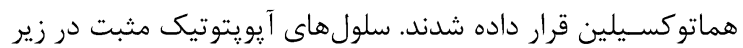
ميكروسكوب به رنغ قهوماى تيره قابلمشاهده بودند .جهت بررسى دئ

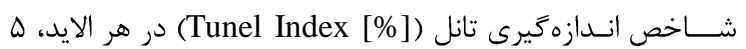

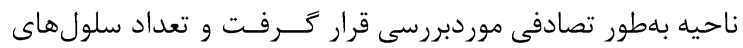

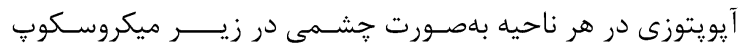

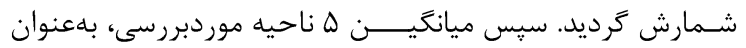

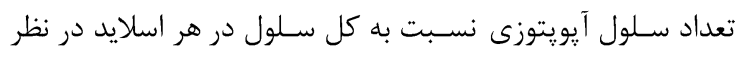

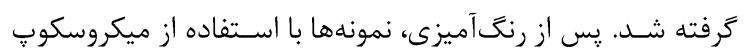

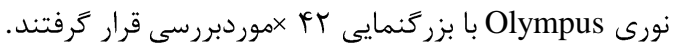

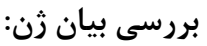
جهت بررسىهاى مولكولى در ســح بيان زن، ابتدا استخراج RNA

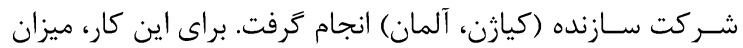

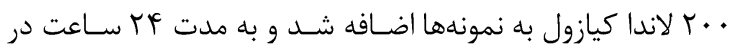

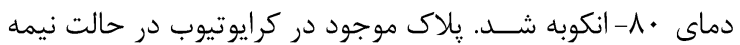

$$
\text { جدول r- توالى يرايمرها }
$$

\begin{tabular}{|l|ll|}
\hline Gene name & Oligo sequence 5' '-3' \\
\hline NLRP1 & F 5' & CAAGAGGGAAAGGTGGACAG 3' \\
& R 5' & GGAAGTGATGGGGATGAAGTGT 3' \\
& & \\
\hline GAPDH & F 5' & AAGTTCAACGGCACAGTCAAGG3' \\
& R 5' & CATACTCAGCACCAGCATCACC3' \\
\hline
\end{tabular}

يس از جمع آورى، بهوسـيله نرمافزار آمارى SPSS نسـخه كT در

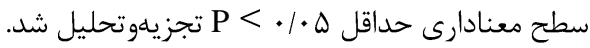

\section{يافتهها}

\section{تغييرات بافتى با روش H\&E و ترى كروماسون:}

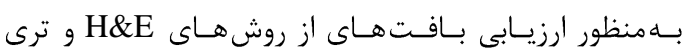

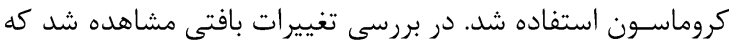

آزمون آمارى:

از ميانكَين و انحراف اسـتاندارد براى گزارش توصـيفى دادهها

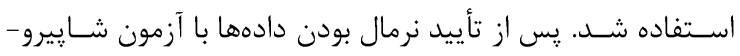

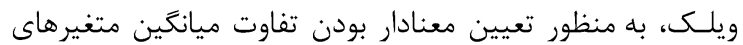

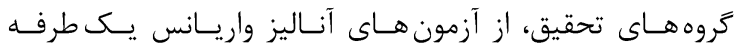
و تست تعقيبى توكى استفاده شد. اطلاعات موردنياز (ANOVA) 


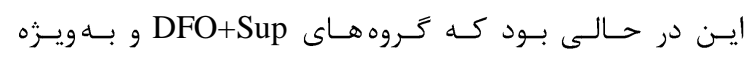
DFO+AE+Sup

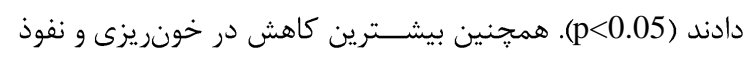

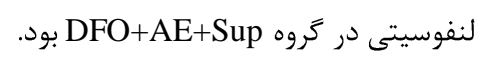

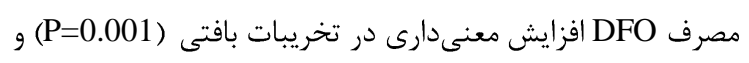

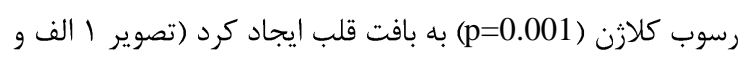

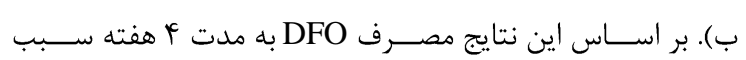
افزايش فيلتراسيون لنفوسيتى شده و ريسك فيبروزيس را بالا برد.

الف)

\section{H\&E staining}
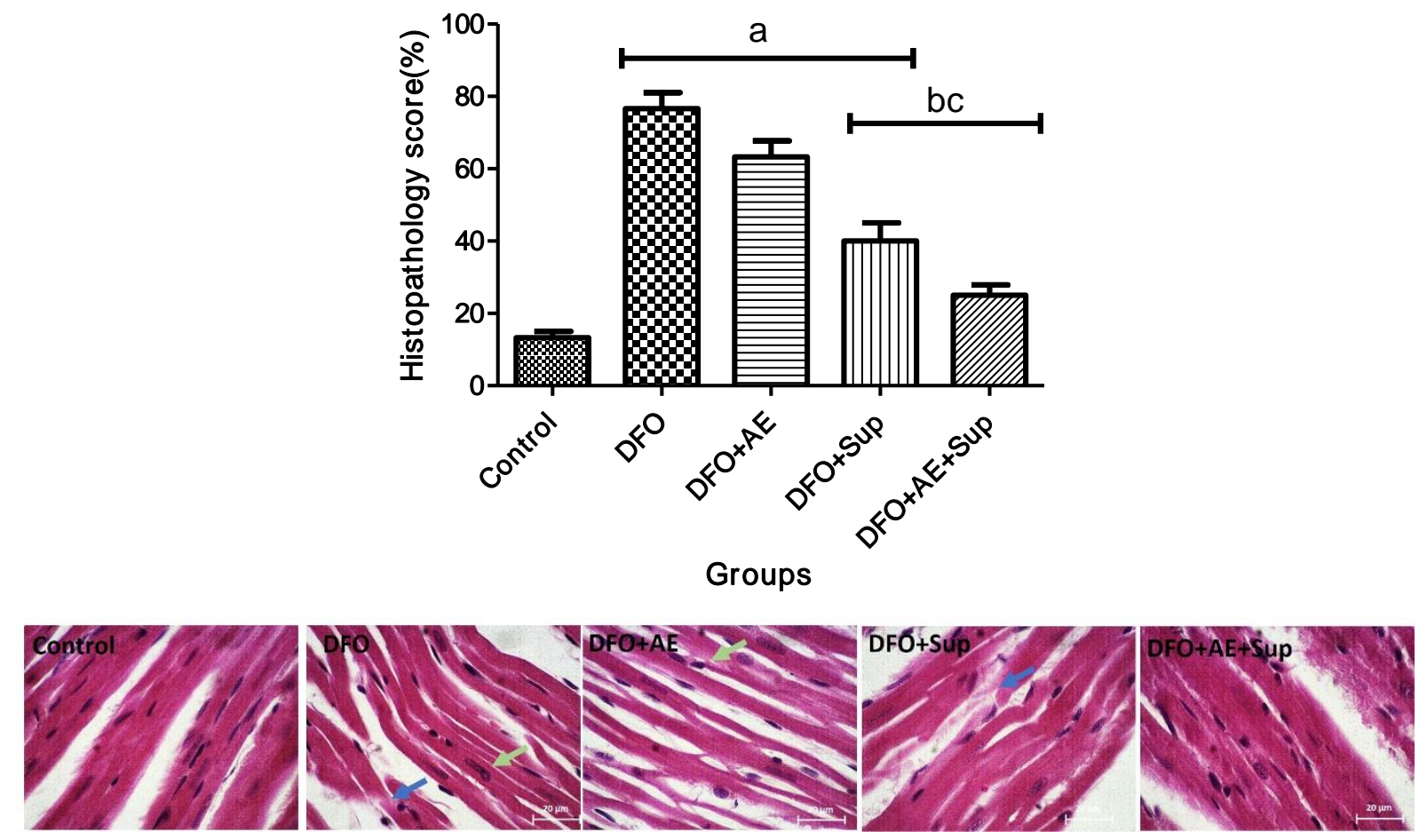

(ب)

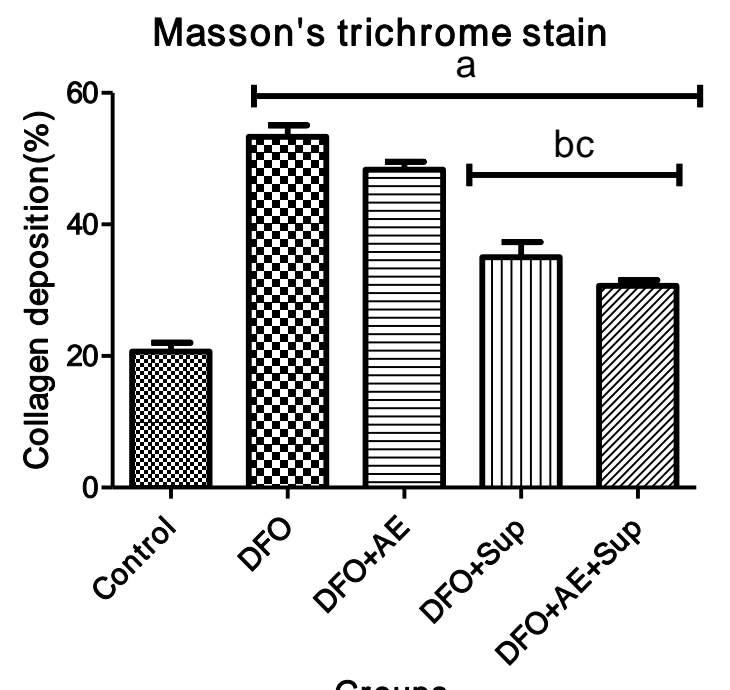

Groups 

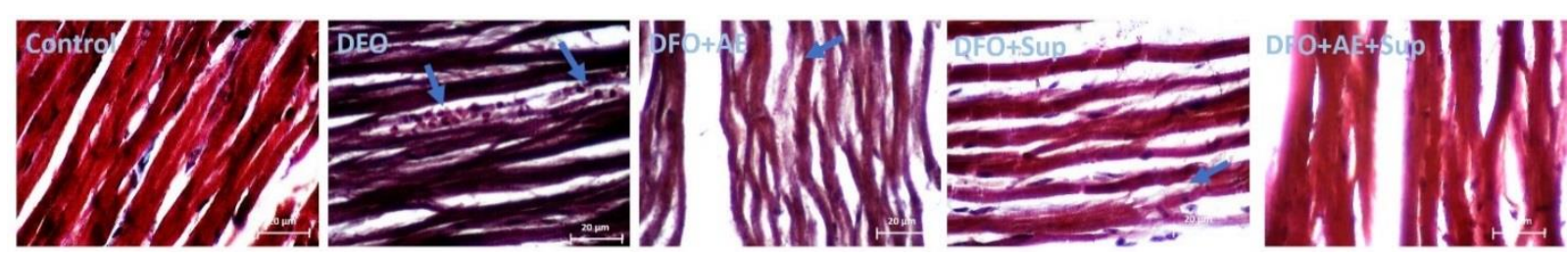

تصوير (1): تغييرات بافتى قلب در كروههاى مختلف يزوهش (الف: تصاوير H\&E، ب: ترى كروماسون) بزركنمايى ·r. فلش آبى نشاندهنده

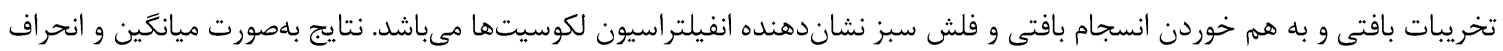

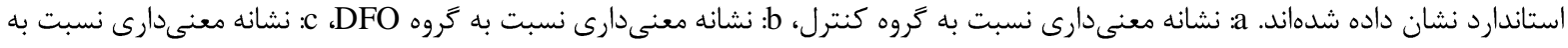

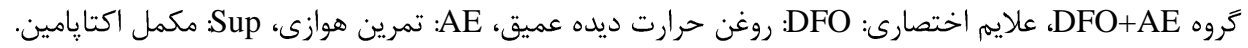

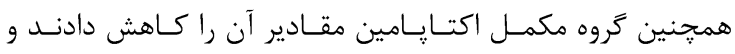

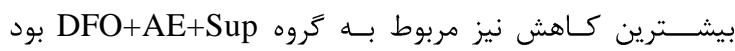

بيان ثن NLRP1:

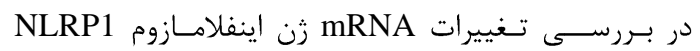

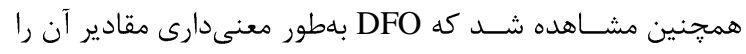

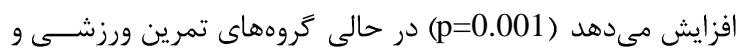

\section{NLRP1}

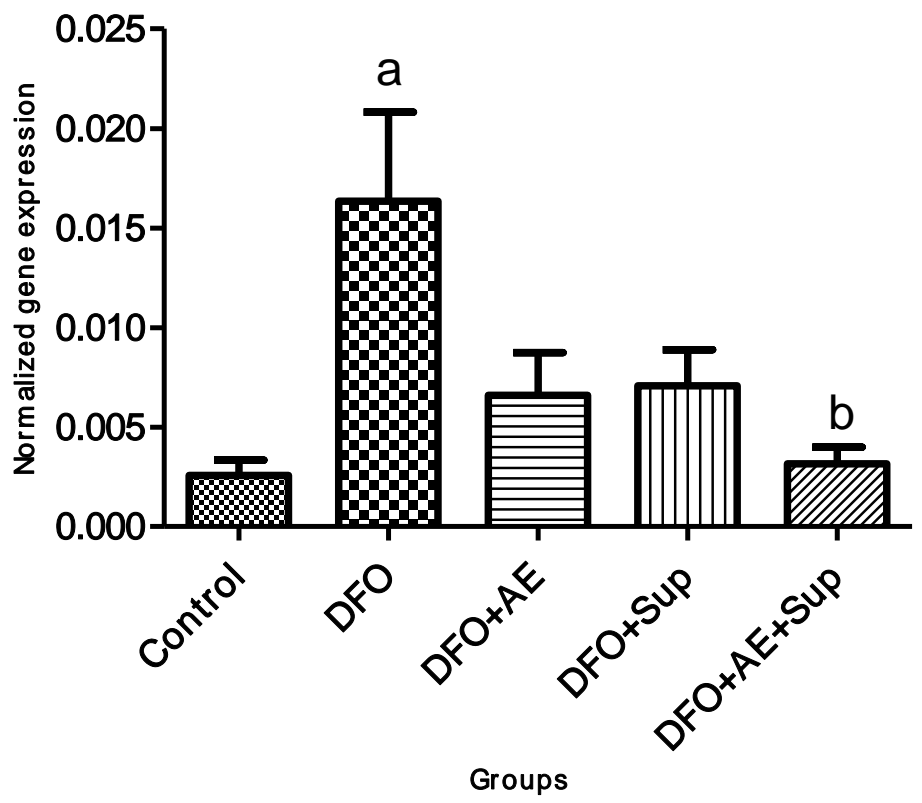

تصوير (Y): تغييرات بيان زنى NLRP1 در عضله قلب در گروههاى مختلف يروهش. نتايج بهصورت ميانگين و انحراف استاندارد نشان داده شدهاند. a: نشانه

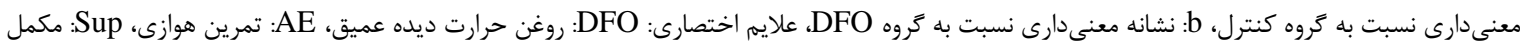
اكتايامين.

بود كه مداخلات درمانى يزوهش حاضر قادر به افزايش اين يروتئنى

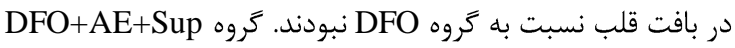

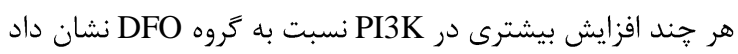
اما اين افزايش معنى دار نبود (p>0.05).
تبروتئين PI3K با روش IHC

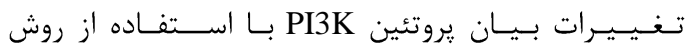

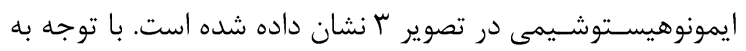

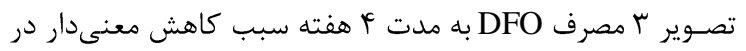

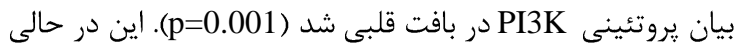




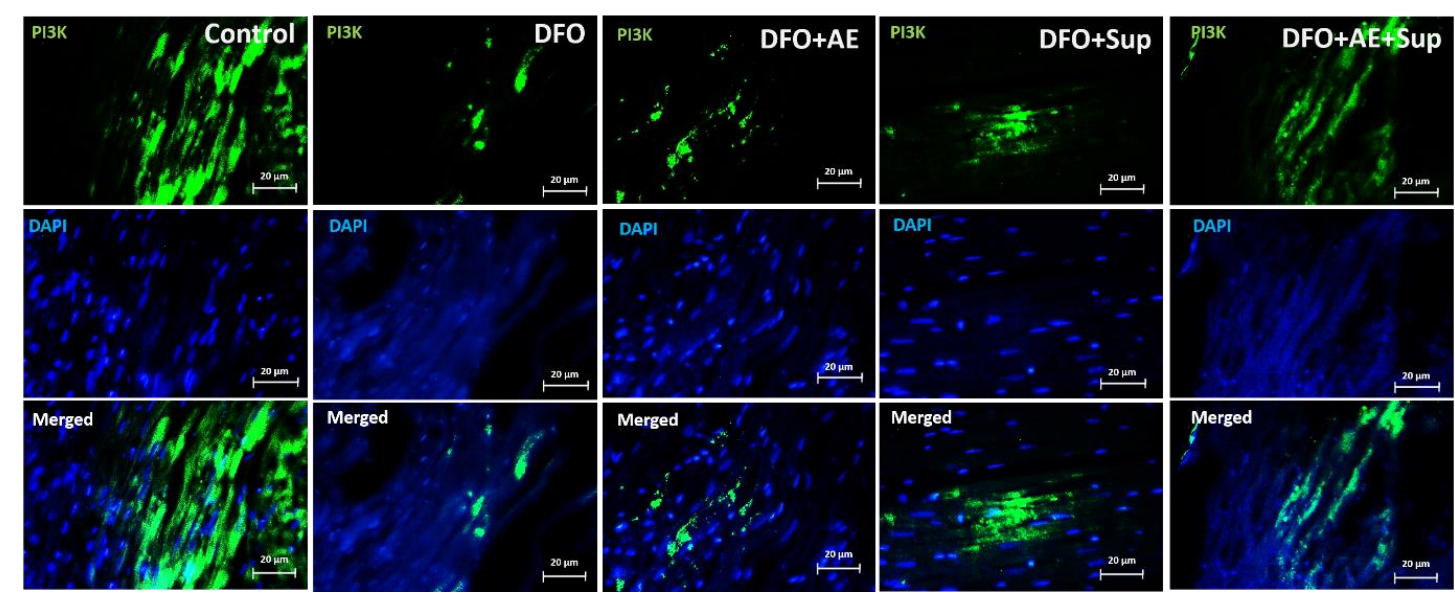

\section{PI3K}

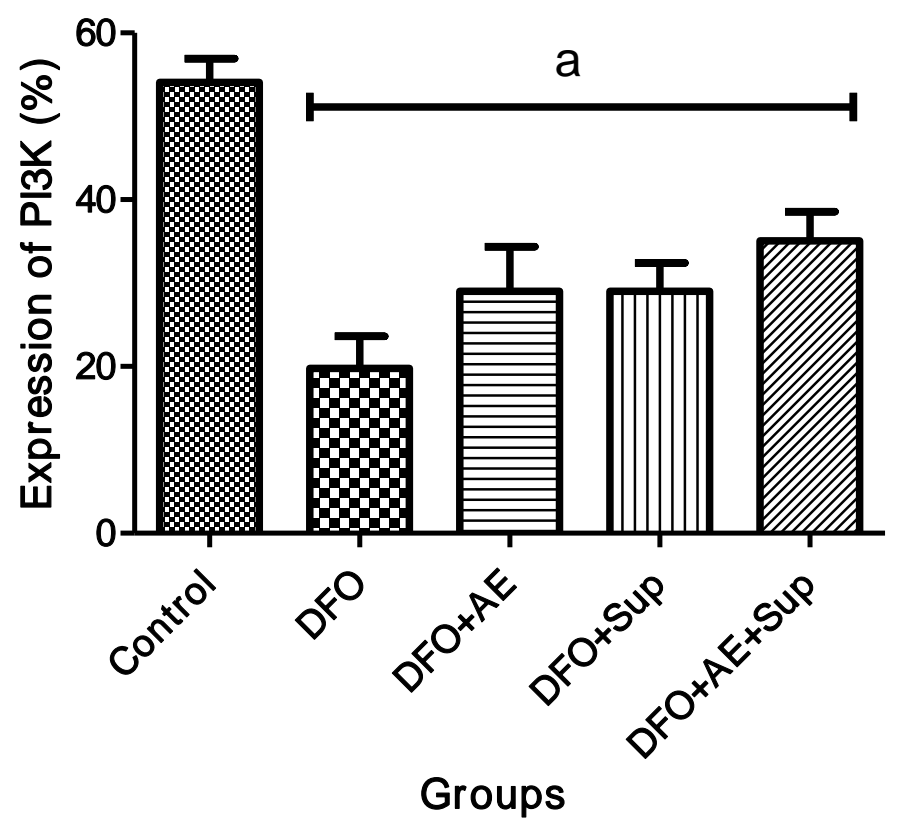

تصوير (ب): تغييرات بيان يروتئينى PI3K در عضله قلب در كروههاى مختلف يزوهش با روش IHC. نتايج بهصورت ميانكَين و انحراف استاندارد نشان داده شدهاند.

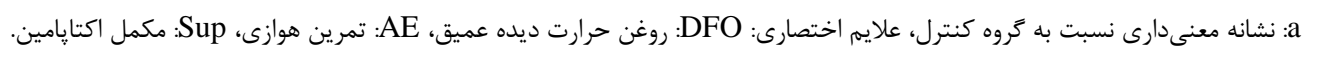

بلهور معنى دارى تخريبات ناشسى از DFO را جبران و سـلولهاى

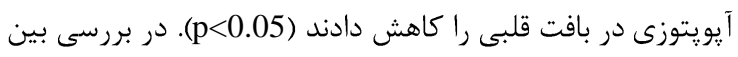

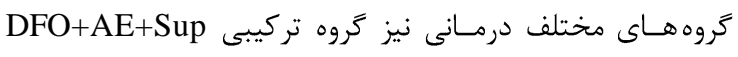

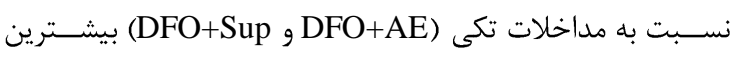
كاهش را در ســلول هاى آيويتوزى نشــان داد كه اين تغييرات نيز

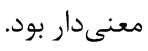

تغييرات سلولهاى آيويتوزى با روش تانل تغييرات سـلولهاى آيويتوزى با روش تانل در تصـوير أ نشان

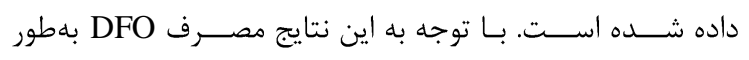

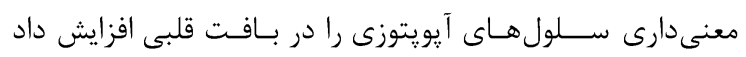

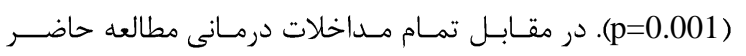

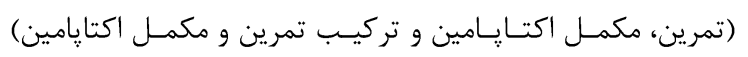




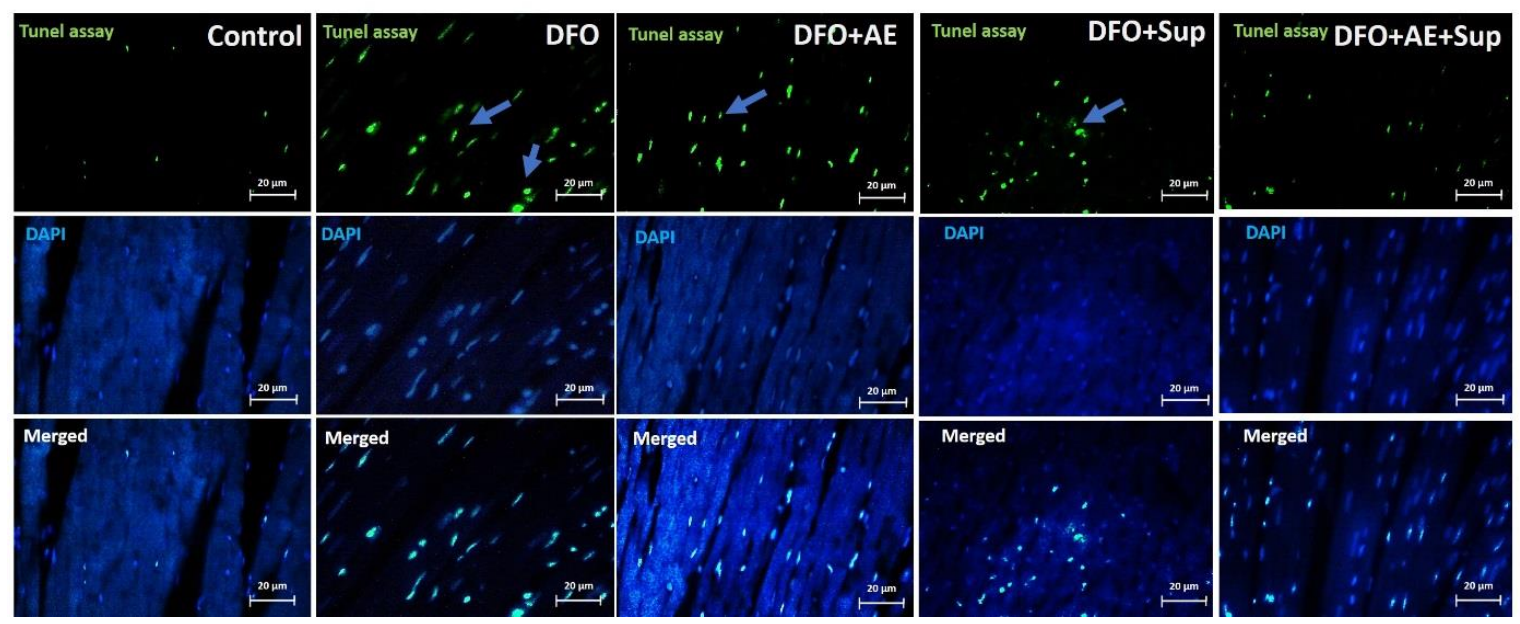

TUNEL assay

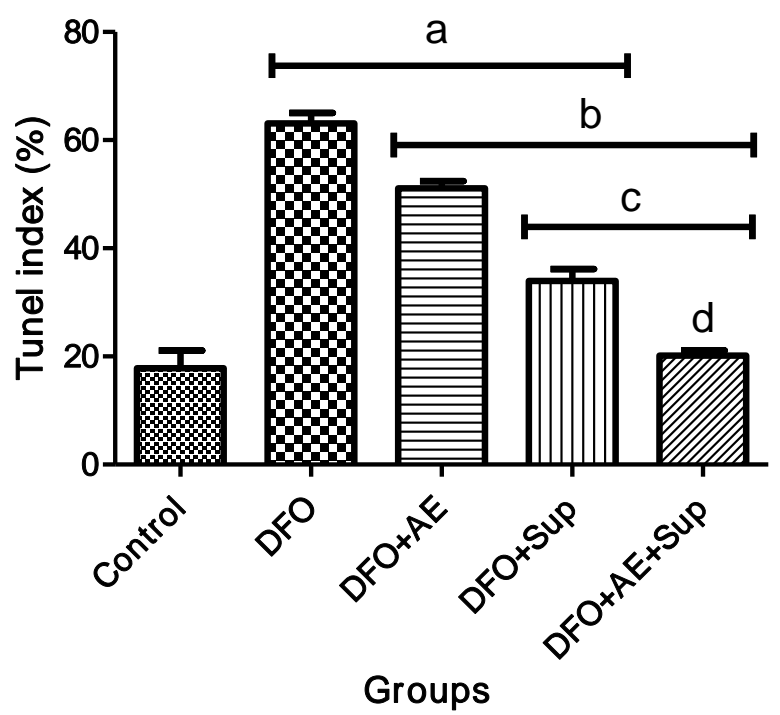

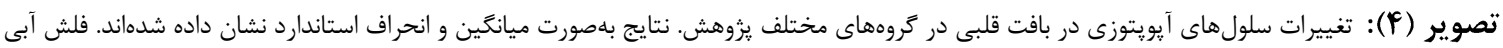

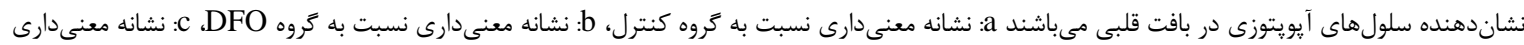

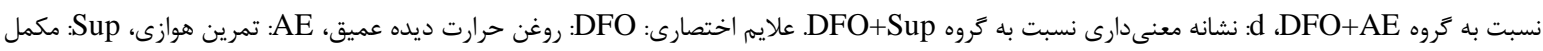
اكتإِامين

شــده و مىتواند در شــروع فيبروزيس نيز دخيل باشـــ. همجنين

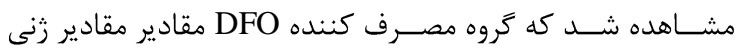

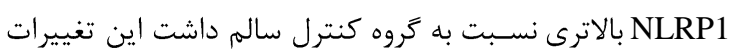

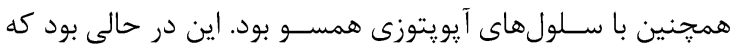

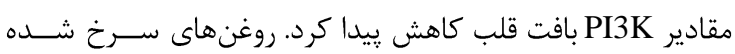

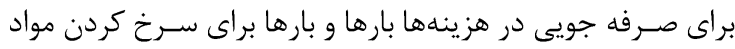

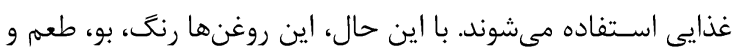

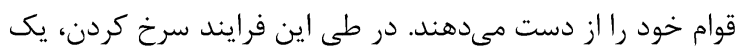

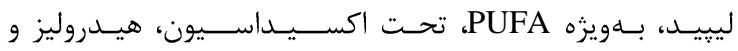

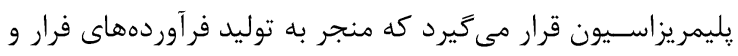

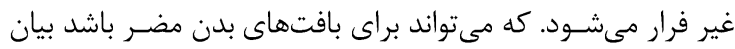

بحث و نتيجه كيرى

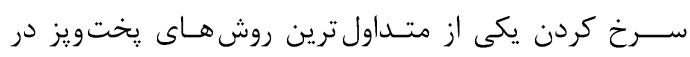

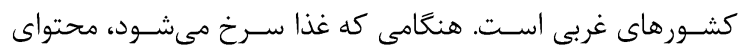

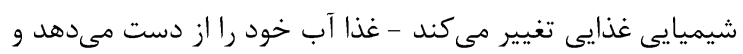

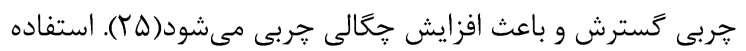

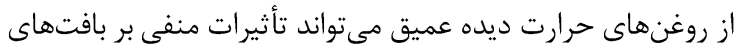
بدن برجاى كذارد. لذا هدف از مطالعه حاضـــر بررسـى دئى تغييرات التهابى و آيويتوزى بافت قلب به دنبال فعاليت بدنى هوازى و مكمل

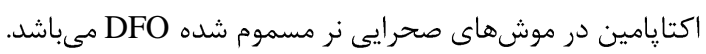

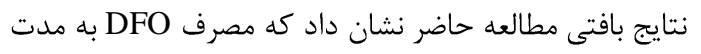

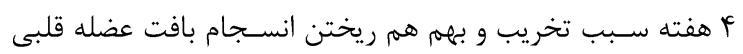




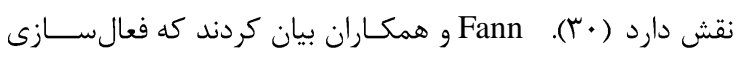

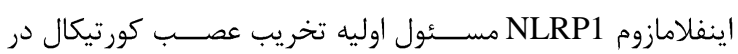

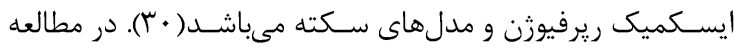

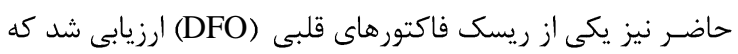

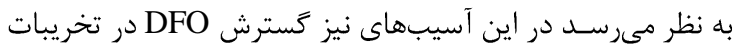

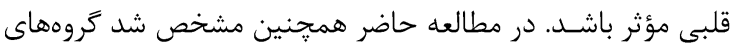

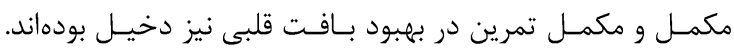

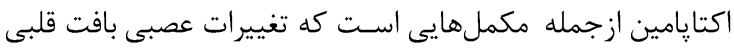

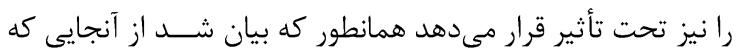

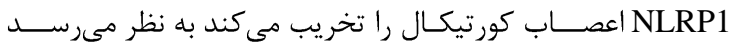

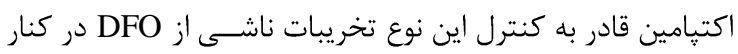

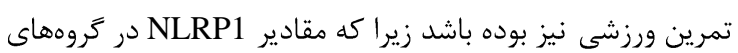
مصـرف كننده مكمل اكتايامين با تمرين ورزشى كاهش راند رانشـان

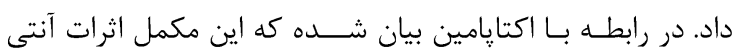
اكسيدانتى بالايى دارد. عصار ههاى ميوه مركبات (نارنج) كه بلعنوان

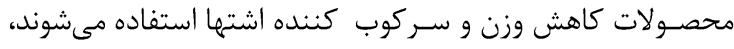

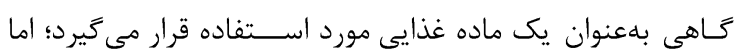

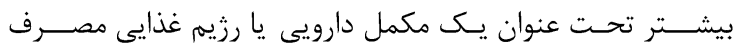

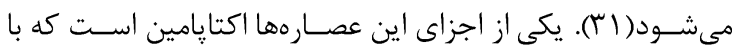

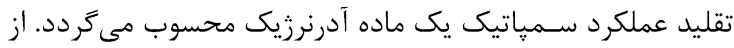

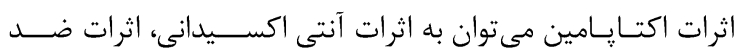

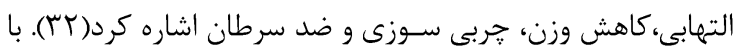

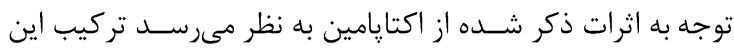

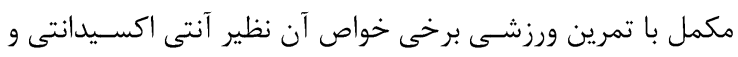

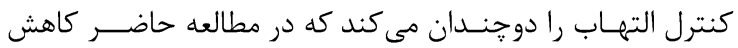
NLRP1

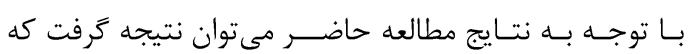
استفاده از مكمل اكتايامين در كنار تمرين ورزشى قادر به كنترل

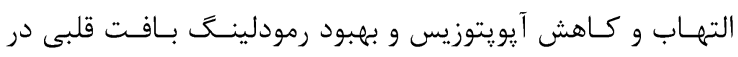

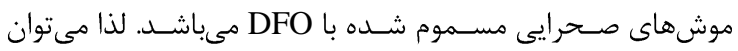

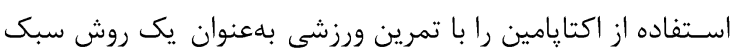

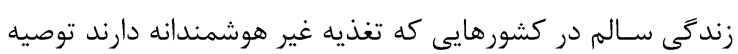
كرد.

ييشـــهاد مىشود در مطالعات آتى به بررسى دوزهاى مختلف

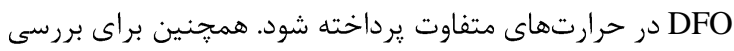

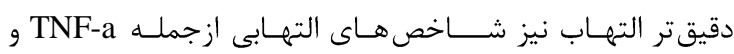
اينترلوكين هاى التهابى با اين فاكتورها در بافت قلبى مورد ارزيابى إنى قرار كيرند.
شـــده كه در هنغام اســتفاده مجدد از اين روغنها فر آيندهاى

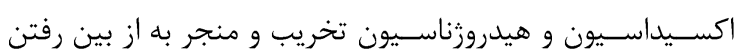

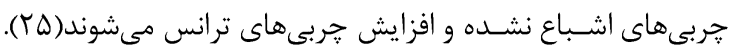

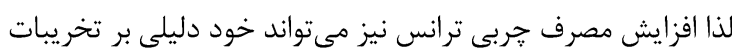

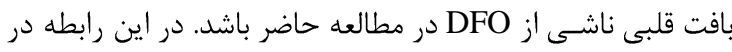
مطالعات مقطعى نيز بيان شـده كه غذاهاى سـرخ شده با خطرات

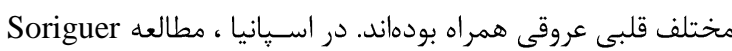

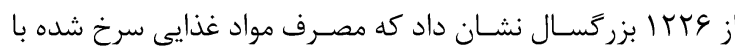
روغنهاى تندبار مصـرف با شـيوع بالاتر فشارخون شريانى همراه

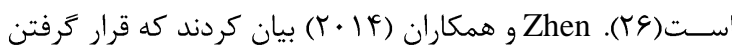

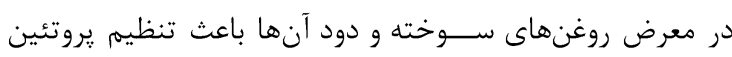

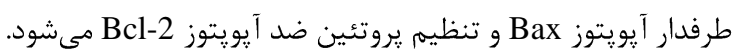

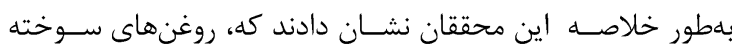

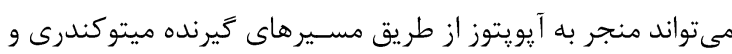

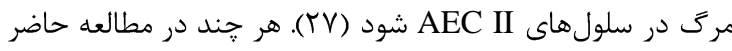

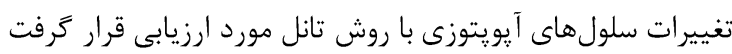

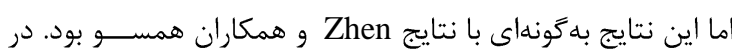

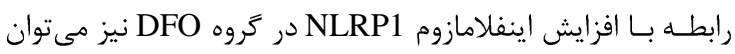

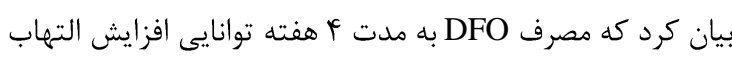

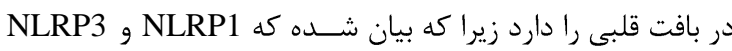

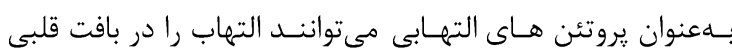

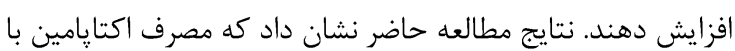
تمرين ورزشى قادر به افزايش PI3K و كاهش سلولهاى آيويتوزى

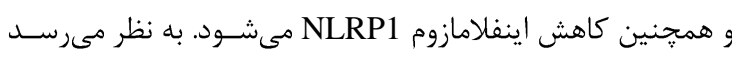

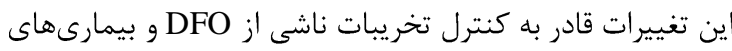

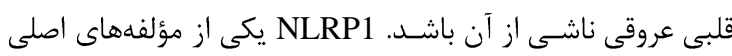

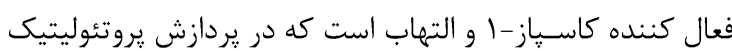

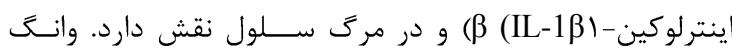

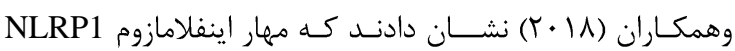

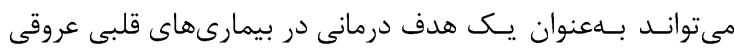

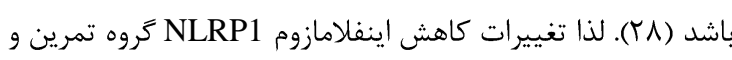

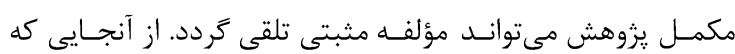

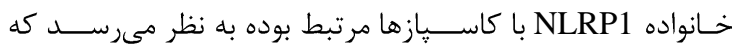
كـاهش ســلول هاى آيويتوزى كروه DFO+AE+Sup در مطالعه حاضر نيز با تنظيم منفى mRNA NLRP مرتبط باشد. نشان داده

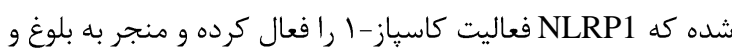

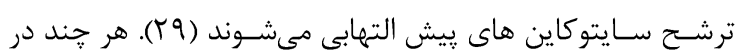

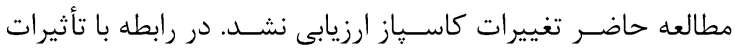

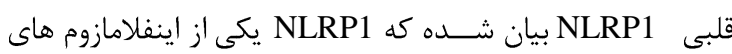
شناخته شده است كه در آسيبهاى ايسكميك ريرفيورن قلبى نيز إنغانيان 


$$
\begin{aligned}
& \text { كليـه زحمـات و مســـاعـدتهاى حوزه معاونت يزوهش و فناورى }
\end{aligned}
$$

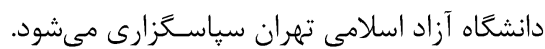

\section{References:}

1. Sacks FM, Lichtenstein AH, Wu JH, Appel LJ, Creager MA, Kris-Etherton PM, et al. Dietary fats and cardiovascular disease: a presidential advisory from the American Heart Association. Circulation 2017;136(3):e1-e23.

2. Saritas T, Floege J. Cardiovascular disease in patients with chronic kidney disease. Herz 2020; $45: 1-7$.

3. Members WG, Thom T, Haase N, Rosamond W, Howard VJ, Rumsfeld J, et al. Heart disease and stroke statistics-2006 update: a report from the American Heart Association Statistics Committee and Stroke Statistics Subcommittee. Circulation 2006;113(6):e85-e151.

4. Choe E, Min D. Chemistry of deep - fat frying oils. Journal of food science 2007;72(5):R77-R86.

5. Ng C-Y, Kamisah Y, Faizah O, Jubri Z, Qodriyah HMS, Jaarin K. Involvement of inflammation and adverse vascular remodelling in the blood pressure raising effect of repeatedly heated palm oil in rats. Int J Vasc Med 2012;2012:404025. 6 . Srivastava S, Singh M, George J, Bhui K, Saxena AM, Shukla Y. Genotoxic and carcinogenic risks associated with the dietary consumption of repeatedly heated coconut oil. $\mathrm{Br} \quad \mathrm{J}$ Nutr 2010;104(9):1343-52.

7. Srivastava S, Singh M, George J, Bhui K, Shukla Y. Genotoxic and carcinogenic risks associated with the consumption of repeatedly boiled sunflower oil. J Agric Food Chem 2010;58(20):11179-86.

8. Dung C-H, Wu S-C, Yen G-C. Genotoxicity and oxidative stress of the mutagenic compounds formed in fumes of heated soybean oil, sunflower oil and lard. Toxicol In Vitro 2006;20(4):439-47.

9. Wu S-C, Yen G-C. Effects of cooking oil fumes on the genotoxicity and oxidative stress in human lung

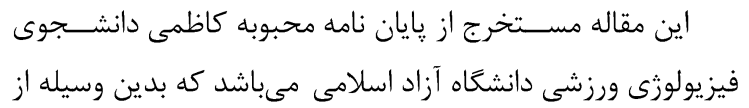

carcinoma (A-549) cells. Toxicol In Vitro 2004;18(5):571-80.

10. Pandey MK, Dhawan A, Das M. Induction of P53, P21Waf1, orinithine decorboxylase activity, and DNA damage leading to cell - cycle arrest and apoptosis following topical application of repeated fish fried oil extract to mice. Mol Carcinog 2006;45(11):805-13.

11. Mehta U, Swinburn B. A review of factors affecting fat absorption in hot chips. Crit Rev Food Sci Nutr 2001;41(2):133-54.

12. Salter A. Dietary fatty acids and cardiovascular disease. Animal 2013;7(s1):163-71.

13. Perez-Herrera A, Rangel-Zuñiga OA, Delgado-Lista J, Marin C, Perez-Martinez P, Tasset I, et al. The antioxidants in oils heated at frying temperature, whether natural or added, could protect against postprandial oxidative stress in obese people. Food Chem 2013;138(4):2250-9.

14. Gupta R, Vind SK, Singh SP, Kumar S, Kumar M. The effect of different deep-fried vegetable oil on cardiovascular system in rats model. World Journal of Pharmaceutical Research 2014;3:1130-9.

15. Bleda S, de Haro J, Varela C, Esparza L, Ferruelo A, Acin F. NLRP1 inflammasome, and not NLRP3, is the key in the shift to proinflammatory state on endothelial cells in peripheral arterial disease. Int $\mathrm{J}$ Cardiol Heart Vasc 2014;172(2):e282-e4.

16. Westin GG, Armstrong EJ, Bang H, Yeo K-K, Anderson D, Dawson DL, et al. Association between statin medications and mortality, major adverse cardiovascular event, and amputation-free survival in patients with critical limb ischemia. J Am Coll Cardiol 2014;63(7):682-90.

17. Ringseis R, Eder K, Mooren FC, Krüger $\mathrm{K}$. Metabolic signals and innate immune activation in 
obesity and exercise. Exerc Immunol Rev 2015;21:58-68.

18. Machado MV, Vieira AB, da Conceição FG, Nascimento AR, da Nóbrega ACL, Tibirica E. Exercise training dose differentially alters muscle and heart capillary density and metabolic functions in an obese rat with metabolic syndrome. Exp Physiol 2017;102(12):1716-28.

19. Hengstmann J, Konen W, Konen C, Eichelbaum M, Dengler H. The physiological disposition of $\mathrm{p}$ octopamine in man. Naunyn Schmiedebergs Arch Pharmacol 1974;283(1):93-106.

20. Beaumont RE, Cordery P, James LJ, Watson P. Supplementation with a low-dose of octopamine does not influence endurance cycling performance in recreationally active men. J Sci Med Sport 2017;20(10):952-6.

21. Kianmehr P, Azarbayjani MA, Peeri M, Farzanegi P. Synergic effects of exercise training and octopamine on peroxisome proliferator-activated receptor-gamma coactivator-1a and uncoupling protein $1 \mathrm{mRNA}$ in heart tissue of rat treated with deep frying oil. Biochemistry and biophysics reports 2020;22:100735.

22. Sujkowski A, Ramesh D, Brockmann A, Wessells R. Octopamine drives endurance exercise adaptations in Drosophila. Cell Rep 2017;21(7):1809-23.

23. Zhou Z, Wang Y, Jiang Y, Diao Y, Strappe P, Prenzler P, et al. Deep-fried oil consumption in rats impairs glycerolipid metabolism, gut histology and microbiota structure. Lipids Health Dis 2016;15(1):86.

24. Bour S, Visentin V, Prévot D, Carpéné C. Moderate weight-lowering effect of octopamine treatment in obese Zucker rats. Cell Physiol Biochem 2003;59(3):175-82.

25. Fillion L, Henry C. Nutrient losses and gains during frying: a review. Int $J$ Food Sci Nutr 1998;49(2):157-68.

26. Soriguer F, Rojo-Martínez G, Dobarganes MC, García Almeida JM, Esteva I, Beltrán M, et al. Hypertension is related to the degradation of dietary frying oils. Am J Clin Nutr 2003;78(6):1092-7.

27. Che Z, Liu Y, Chen Y, Cao J, Liang C, Wang L, et al. The apoptotic pathways effect of fine particulate from cooking oil fumes in primary fetal alveolar type II epithelial cells. Mutat Res Genet Toxicol Environ Mutagen 2014;761:35-43.

28. Wang W, Wang C, Gong Y, Zhang X. Inhibition of NLRP1 inflammasome might be a novel therapeutic target in the treatment of peripheral arterial disease. International journal of cardiology 2018;256:29.

29. Yi Y-S. Role of inflammasomes in inflammatory autoimmune rheumatic diseases. Korean J Physiol Pharmacol 2018;22(1):1-15.

30. Fann DY-W, Lee S, Manzanero S, Tang S-C, Gelderblom M, Chunduri P, et al. Intravenous immunoglobulin suppresses NLRP1 and NLRP3 inflammasome-mediated neuronal death in ischemic stroke. Cell Death Dis 2013;4(9):e790-e.

31. Thevis M, Koch A, Sigmund G, Thomas A, Schänzer W. Analysis of octopamine in human doping control samples. Biomed Chromatogr 2012;26(5):610-5.

32. De Oliveira AL, De Paula MN, Comar JF, Vilela VR, Peralta RM, Bracht A. Adrenergic metabolic and hemodynamic effects of octopamine in the liver. Int J Mol Sci 2013;14(11):21858-72. 


\title{
THE EFFECT OF ENDURANCE EXERCISE TRAINING AND OCTOPAMINE SUPPLEMENTATION ON NLRP1 INFLAMMASOME, PI3K, APOPTOSIS, AND HISTOPATHOLOGICAL CHANGES IN HEART TISSUE OF RATS POISONED WITH DEEP-FRIED OIL
}

\author{
Mahboubeh kazemi dareh bidi ${ }^{1}$, Maghsoud Peeri ${ }^{2 *}$, Mohamad Ali Azarbayjani1 $^{r}$
}

\begin{abstract}
Received: 23 June, 2020; Accepted: 14 October, 2020

Background \& Aims: Common nutritional mistakes cause inflammation and homeostasis disruption in heart cells. Inflammasome complex is one of the pathways that induces inflammation and degradation of cardiac protein regeneration. The aim of the present study was to investigate changes in NLRP1inflammasome, PI3k, apoptosis, and histopathology of heart tissue following aerobic physical activity and octopamine supplementation in male rats poisoned with deep-fried oil (DFO).

Materials \& Methods: 30 Wistar male rats (300 to $350 \mathrm{~g}$ ) were randomly divided into 5 groups $(\mathrm{n}=6)$ : control, deep-fried oil, deep-fried oil + aerobic exercise, deep-fried oil + octopamine supplement (Sup), and deep-fried oil + aerobic exercise + octopamine. During the study, DFO was orally administered to the rats (gavage $10 \mathrm{ml} / \mathrm{kg}$ ) for 4 weeks (morning). The dose of octopamine was $81 \mathrm{~mol} / \mathrm{kg}$ (Intraperitoneal injection) and dissolved in 9\% normal saline. It was injected into supplement groups 2 hours after the exercise program. The rats in the training group also exercised at a moderate intensity at $50 \%$ vo2max in the first week and 65\% vo2max in the last week. Changes in NLRP1 gene expression and PI3k protein expression were performed by RT Pcr and IHC. The tunnel assay was also used to evaluate apoptotic cells.

Results: Consumption of DFO caused a significant increase in tissue damage $(\mathrm{p}=0.001)$ and collagen deposition $(\mathrm{p}=0.001)$ to heart tissue. Also, DFO gavage for 4 weeks in rat model increased tissue damage, mRNA NLRP1 inflammasome, and apoptotic cells $(\mathrm{p}=0.001)$ and also significantly decreased protein expression of PI3K $(\mathrm{p}=0.001)$. Examination of tissue changes also revealed that deep-fried oil + octopamine and deep-fried oil + aerobic exercise + octopamine groups showed a significant decrease in collagen deposition $(\mathrm{p}<0.05)$. Therapeutic interventions also reduced the levels of mRNA NLRP1 and Apoptosis cell and increased protein expression of PI3K. Most of these changes were related to the deep-fried oil + aerobic exercise + octopamine group $(\mathrm{p}<0.05)$.

Conclusion: The results of the present study showed that taking octopamine with aerobic exercise for 4 weeks can control the inflammasome complex (reduction of NLRP1 mRNA) followed by reduction of apoptosis and improvement of cardiac cell regeneration capacity (PI3K protein expression) in the model of nutritional disorders induced by DFO. Therefore, it can be concluded that octopamine supplementation with exercise can have a cardiac protection effect in non-smart nutritional conditions. Keywords: Inflammasome complex, aerobic physical activity, deep-fried oil, heart, apoptosis
\end{abstract}

Address: Department of Exercise Physiology, Central Tehran Branch, Islamic Azad University, Tehran, Iran

Tel: +989121124434

Email: m.peeri@iauctb.ac.ir

SOURCE: STUD MED SCI 2020: 31(9): 679 ISSN: 2717-008X

\footnotetext{
${ }^{1}$ Department of Exercise Physiology, Central Tehran Branch, Islamic Azad University, Tehran, Iran

${ }^{2}$ Department of Exercise Physiology, Central Tehran Branch, Islamic Azad University, Tehran, Iran (Correspondin Author)

${ }^{3}$ Department of Exercise Physiology, Central Tehran Branch, Islamic Azad University, Tehran, Iran
} 